\title{
Como quem planta árvores
}

\section{IVAN VILELA}



OFÍCIO DE compositor muitas vezes nos coloca em um estado de observação como se tivéssemos que extrair música de tudo o que se divulga em nossa frente. Às vezes são paisagens, às vezes são sons, ora da natureza criadora do homem ora da natureza criativa do homem. Às vezes são sensações - paisagens da alma -, às vezes premonições. O compositor anda atento aos movimentos físicos e metafísicos do mundo que o cerca e o envolve.

Quando li Guimarães Rosa pela primeira vez já era eu um adulto. Desavisadamente fui lendo como leria qualquer outro texto. Tive a sensação de estar viajando em uma estrada cheia de buracos. Parei. Idas anteriores ao norte de Minas me trouxeram, súbito, a imagem sonora da fala do povo de lá. Voltei a ler como eles falavam, como a gente lê poesia, lentamente e em voz alta. Foi como se uma imagem de terceira dimensão pulasse à minha frente. Um outro universo foi criado e uma música começou a jorrar daquele texto. Não uma música que eu compunha, mas sim uma que já estava lá, composta pelo próprio autor.

Ocorreu-me que João Rosa era músico e aquele texto era puro devaneio sonoro. Seu ritmo híbrido, suas inúmeras fórmulas de compasso, números primos, quiálteras, superposições rítmicas, contrapontos. Era tudo de uma complexidade singular; diversa, como diria o autor.

Percebi então que aquele músico escritor era imperativo ao exigir de nós, leitores, que lêssemos entoando a música que ele imaginou, no andamento que ele quis e com a entoação que ele sonhara.

Era uma música idiomática que brotava a partir de uma cultura e um lugar específicos. No entanto, suas sagas, suas histórias, por mais localizadas que fossem, eram universais, pois tratavam de dramas presentes na existência humana; que são iguais aqui, nas savanas africanas, nas areias do Oriente próximo, nas montanhas do Himalaia ou nas ilhas do Oriente distante.

Aquele texto iluminou minha música, aquele homem me trouxe outros sons. A viola que eu já conhecia tomou outra forma nas minhas mãos depois de ler Guimarães Rosa. Pediu-me para ser usada de outra maneira: idiomática, que já era, e agora, universal.

Há obras que são datadas e outras que são perenes. Há criadores que criam para o momento e criadores que criam para a eternidade. Nesses, a arte ganha uma capacidade alquímica de transubstanciação no nosso interior. Rosa criou para a eternidade, e sua leitura, nos dias de hoje, se torna mais premente e necessária. Talvez porque fomos criados a partir dos mesmos valores que nor- 


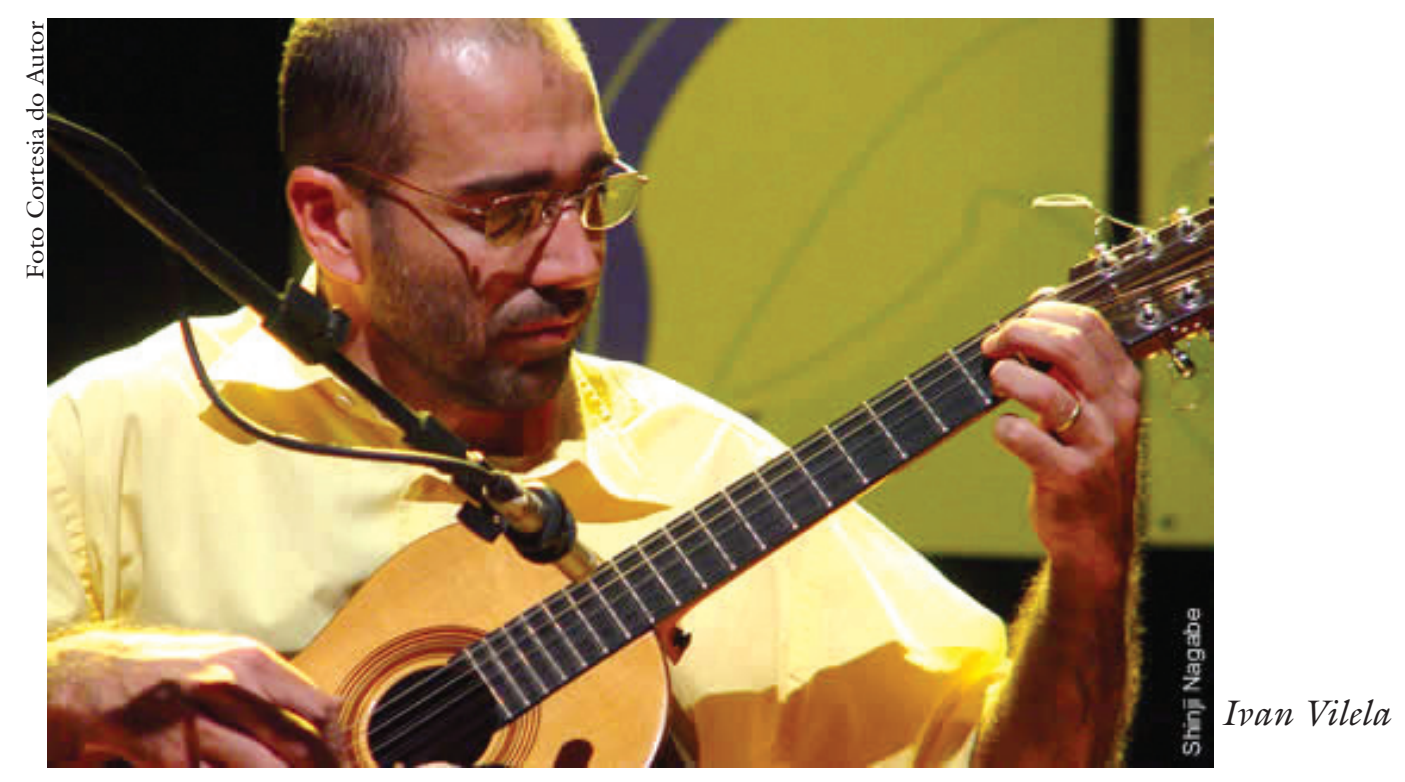

tearam a criação de nossos pais, avós e bisavós, algo que Rosa chamou de brasilidade. Invocado por Günter Lorenz durante uma entrevista, ${ }^{1}$ Rosa responde "É lógico que existe a 'brasilidade'. Existe como uma pedra básica de nossas almas, de nossos pensamentos, de nossa dignidade, de nossos livros e de toda a nossa forma de viver". Depois conclui... "brasilidade é um sentir-pensar". O que Rosa chama de brasilidade foi algo amalgamado no dia-a-dia de todos os nossos ancestrais a ponto de se tornar, com o tempo, valores fundadores de nós, hoje, de nosso povo, de nossa cultura.

De uns vinte anos para cá começou a se configurar um esforço de ruptura na preservação desses valores. O espaço lúdico da rua deixou de ser a fonte de manutenção do imaginário popular infantil; a mídia, pouco a pouco, foi suprindo a capacidade imaginativa e imagética de muitos; a produção artística busca agora atender à demanda de um mercado, à imposição de um valor delineado e um gosto predefinido. Paulatinamente, essa brasilidade vem cedendo espaço a um novo tipo de cultura: a do consumo.

Ao mesmo tempo, sorrateiramente, nos quintais, crescem movimentos de auto-afirmação das próprias raízes. Um gosto novo pelo velho, pelo que dançavam nos interiores, pelo que cantavam nos lugares de-dentro.

Neste momento reparamos que nunca um autor brasileiro foi tão celebrado, tão encenado, tão cantado, tão dançado, tão pintado, tão esculpido, tão reescrito, tão recriado como Guimarães Rosa tem sido. Ponho-me a imaginar que pode não ser por acaso que aconteça tal resgate.

Rosa diz a Günter Lorenz: "sou um sertanejo e acho maravilhoso que você deduzisse isso lendo meus livros, porque significa que você os entende". E mais adiante "esse 'homem do sertão' está presente como ponto de partida mais do que qualquer outra coisa". ${ }^{2}$ 
Esse resgate polissêmico que se processa atualmente com sua obra é uma atitude consciente-inconsciente de - nesse mar de uniformizações - chamarmos a nós algo que é nosso, a nossa singularidade, a brasilidade que nos funda, a cada instante, como povo. Rosa, incessantemente, nos convida a olharmos o mundo com nossos próprios filtros, com nossas próprias lentes.

Resgatar Guimarães Rosa é trazer novamente à nossa vida algo como a fruição e a transcendência. Talvez possam ser essas palavras que faltem em nosso vocabulário do dia-a-dia. Rosa as tem, tem o remédio de que agora precisamos. Longe da xenofobia, porque sempre fomos uma cultura de soma, precisamos de raizes e transcendência. Curiosamente, para nós que mantemos em nossas pesquisas o contato direto com os interiores do Brasil, a palavra raiz sempre nos leva a outra, transcendência. E disso Rosa sempre soube.

Notas

1 Entrevista de Guimarães Rosa concedida a Günter Lorenz, em João Guimarães Rosa, Ficção completa, Rio de Janeiro: Nova Aguilar SA, 1995, v.I, p.55.

2 Ibidem, p.30.

Ivan Vilela, músico e compositor, é professor do Departamento de Música de Ribeirão Preto da Escola de Comunicações e Artes da USP. É bacharel e mestre em Composição Musical pela Universidade Estadual de Campinas (Unicamp). Possui vários CDs gravados, e os mais recentes são: Caipira (2004), clássicos da músicas caipira ao som da viola e das vozes de Suzana Salles e Lenine Santos; Orquestra Filarmônica de Violas (2004), clássicos da música sertaneja interpretados por vinte violas; Quatro Estórias (2002), estórias de Rubem Alves musicadas por Ivan Vilela.

@ - ivanvilela@usp.br / Site: http://www.ivanvilela.com.br/index.html

Recebido em 2.10.2006 e aceito em 3.10.2006. 